\title{
Pengaruh Diklat Santri Siap Guna terhadap Peserta Pelatihan
}

\author{
Dadan Darmawan ${ }^{凶}$ \\ Pendidikan Luar Sekolah Universitas Tirtayasa Banten
}

DOI: $10.15294 /$ pls.v1i2.19420

\begin{tabular}{l} 
Info Artikel \\
\hline Sejarah Artikel: \\
Diterima Oktober 2017 \\
Disetujui November 2017 \\
Dipublikasikan Desember 2017 \\
\hline Keywords: \\
education and training; \\
prepared islamic students; work \\
performance; work motivation; \\
productivity; competence
\end{tabular}

\begin{abstract}
Abstrak
Tujuan penelitian menganalisis pengaruh pendidikan dan pelatihan santri siap guna terhadap kinerja, motivasi kerja, produktivitas, dan kompetensi peserta pelatihan. Metode yang di gunakan dalam penelitian ini adalah metode deskriptif kuantitatif. Data Primer diperoleh menggunakan angket, sedangkan data sekunder melalui wawancara dan dokumentasi. Responden penelitian terdiri dari pengelola dan peserta yang telah lulus pelatihan. Hasil penelitian didapatkan bahwa 80,83\% peserta yang termasuk kategori sangat setuju, berpendapat sangat setuju bahwa pelatihan berpengaruh pada peserta yang dilaksanakan dalam kehidupan sehari-hari. Diukur dengan 4 indikator, diantaranya adalaha kinerja sebesar $19,67 \%$, motivasi sebesar $16,17 \%$, produktivitas sebesar $15,41 \%$ dan kompetensi mencapai 80,64\%.
\end{abstract}

\section{Abstract}

The purpose of the study analyzed the influence of education and training of students ready for the performance, work motivation, productivity, and competence of trainees. The method used in this research is descriptive quantitative method. Primary data were obtained using questionnaire, while secondary data was through interview and documentation. Research respondents consist of managers and participants who have passed the training. The results showed that $80.83 \%$ of participants who belong to the category strongly agreed, argued strongly agree that the training effect on participants who carried out in daily life. Measured by 4 indicators, among them is the performance of $19.67 \%$, motivation of $16.17 \%$, productivity of $15.41 \%$ and competence reached $80.64 \%$. 


\section{PENDAHULUAN}

Indonesia adalah negara yang memiliki jumlah penduduk yang besar. Bila kualitas dan pendayagunaannya dikembangkan dan ditingkatkan, maka bukan suatu ketidakmungkinan dalam waktu relatif singkat perekonomian yang sedang mengalami krisis ini, akan mengalami pertumbuhan dan berkembang dengan pesat dan memberikan tingkat pendapatan nasional yang relatif tinggi. Oleh karena itu, tantangan yang bangsa ini hadapi sekarang dan untuk masa yang akan datang adalah mempersiapkan sumber daya manusia yang berkualitas, terampil, memiliki inovasi dan kreativitas yang tinggi, memiliki daya analisis dan pandangan jauh ke depan untuk mewujudkan pembangunan nasional.

Undang-Undang No. 20 Tahun 2003 tentang Sistem Pendidikan Nasional Pasal 1 ayat 1 dan 2 memberikan penjelasan bahwa pendidikan adalah usaha sadar dan terencana untuk mewujudkan suasana belajar dan proses pembelajaran agar peserta didik secara aktif mengembangkan potensi dirinya untuk memiliki kekuatan spiritual keagamaan, pengendalian diri, kepribadian, kecerdasan, akhlak mulia, serta keterampilan yang diperlukan dirinya, masyarakat bangsa dan negara. Pendidikan nasional adalah pendidikan yang berdasarkan Pancasila dan Undang-Undang Dasar Negara Republik Indonesia Tahun 1945 yang berakar pada nilai-nilai agama, kebudayaan nasional Indonesia dan tanggap terhadap tuntutan perubahan zaman. Untuk mewujudkan harapan dari penyelenggaraan pendidikan di Indonesia yang di jelaskan pada ayat tersebut, tentunya tidak bisa mengandalkan satu jalur pendidikan saja, namun semua jalur pendidikan yang digariskan menurut Undang-Undang No 20 Tahun 2003 tentang Sistem Pendidikan Nasional. Adapun jalur pendidikan yang dimaksud yaitu terdapat dalam Pasal 13 ayat 1 , disebutkan bahwa "jalur pendidikan terdiri atas pendidikan formal, nonformal, dan informal yang dapat saling melengkapi dan memperkaya". Penjelasan dari ketiga jalur tersebut terdapat dalam Pasal 1 ayat 11, 12, 13, yakni: pendidikan formal adalah jalur pendidikan yang terstruktur dan berjenjang yang terdiri atas pendidikan dasar, pendidikan menengah, dan pendidikan tinggi. Pendidikan nonformal adalah jalur pendidikan di luar pendidikan formal yang dapat dilaksanakan secara terstruktur dan berjenjang. Pendidikan informal adalah jalur pendidikan keluarga dan lingkungan.

Penjelasan dari ketiga jalur pendidikan yaitu formal, nonformal, dan informal kemudian dipertegas oleh Sudjana (2004:22) sebagai berikut,

Pendidikan formal adalah kegiatan yang sistematis, berstruktur, bertingkat, berjenjang, dimulai dari sekolah dasar, sampai dengan perguruan tinggi dan yang setaraf dengannya; termasuk ke dalamnya kegiatan studi yang berorientasi akademis dan umum, program spesialisasi, dan latihan profesional yang dilaksanakan dalam waktu yang terus menerus. Pendidikan informal adalah proses yang berlangsung sepanjang usia sehingga setiap orang memperoleh nilai sikap, keterampilan dan pengetahuan yang bersumber dari pengalaman hidup seharihari, pengaruh lingkungan termasuk di dalamnya pengaruh kehidupan keluarga, hubungan dengan tetangga, lingkungan pekerjaan dan permainan, pasar, perpustakaan, dan media massa. Pendidikan nonformal adalah setiap kegiatan teroganisasi dan sistematis di luar sistem persekolahan yang mapan, dilakukan secara mandiri atau merupakan bagian penting dari kegiatan yang lebih luas, yang sengaja dilakukan untuk melayani peserta didik tertentu di dalam mencapai tujuan belajarnya.

Jalur pendidikan yang memiliki istilah tidak mengenal batas usia untuk belajar adalah pendidikan nonformal. Salah satu program pendidikan nonformal adalah pendidikan kecakapan hidup (life skills). Adapun tujuan pendidikan kecakapan hidup yang diutarakan oleh Depdiknas (2004:2) sebagaimana berikut,

1) Memiliki pengetahuan, keterampilan dan sikap yang dibutuhkan dalam memasuki dunia kerja, baik bekerja secara mandiri (wirausaha) dan/atau bekerja pada suatu perusahaan produksi/jasa dengan penghasilan yang semakin layak untuk memenuhi kebutuhan hidupnya.

2) Memiliki motivasi dan etos kerja yang tinggi serta dapat menghasilkan karya- 
karya yang unggul dan mampu bersaing di pasar global.

3) Memiliki kesadaran yang tinggi tentang pentingnya pendidikan untuk dirinya sendiri maupun untuk anggota keluarganya.

4) Memiliki kesempatan yang sama untuk memperoleh pendidikan dalam rangka mewujudkan keadilan pendidikan disetiap lapisan masyarakat.

Tujuan tersebut sejalan dengan tujuan program pelatihan santri siap guna (SSG) yang dilaksanakan, adalah pelatihan yang sangat dibutuhkan setiap insan manusia untuk pengembangan dirinya dari akhlak sampai dengan potensi yang dimiliki sesuai dengan tujuan dan arah yang di siapkan oleh santri siap guna (SSG) yaitu mempersiapkan peserta didik untuk mempunyai akhlak yang baik, kuat, mendapat pekerjaan yang layak, kemapanan untuk kehidupan perekonomian, peningkatan taraf hidup-nya serta bahagia di dunia dan akhirat. Sejauh ini tujuan tersebut tercapai dari banyaknya peserta didik yang telah berubah akhlak dan potensi pada dirinya, bahkan langsung bekerja setelah selesai mengikuti program pelatihan.

Kondisi riil yang ada di lapangan sebagaimana pendidikan nonformal, salah satunya terdapat pada kegiatan program Santri Siap Guna (SSG) di Yayasan Daarut Tauhid Kota Bandung. Program kegiatan tersebut sebagaimana program pelatihan. Pelatihan dilakukan dengan tujuan untuk meningkatkan pengetahuan dan keterampilan seseorang agar mereka yang dilatih mendapat pengetahuan dan keterampilan dalam memahami dan melaksanakan suatu pekerjaan dengan efektif dan efisien. Dengan kata lain tujuan pelatihan adalah meningkatkan kinerja dan pada gilirannya akan meningkatkan daya saing. Masih terkait dengan tujuan pelatihan, Simamora (1997) mengutarakan tujuan-tujuan pelatihan, pada intinya dapat di kelompokkan dalam lima bidang di antaranya memperbaiki kinerja. Sementara itu, Sikula dalam Sumantri (2000) mengartikan pelatihan sebagai proses pendidikan jangka pendek yang menggunakan cara dan prosedur yang sistematis dan terorganisir. Para peserta pelatihan akan mempelajari pengetahuan dan keterampilan yang sifatnya praktis untuk tujuan tertentu.

Pelatihan adalah suatu proses belajar mengenai sebuah wacana pengetahuan dan keterampilan yang di tujukan untuk penerapan hasil belajar yang sesuai dengan tuntutan tertentu. Oleh karenanya, "pelaksanaan pelatihan memerlukan prosedur atau langkahlangkah agar pelatihan dapat berjalan dengan baik" (Kamil, 2010:155). Terdapat berbagai model pelatihan sebagai kegiatan pendidikan luar sekolah. Model-model itu terutama dilihat dari tujuan pelatihan yang kemudian menentukan proses pelatihan. "Setiap model memiliki karakteristik sendiri dan kelemahnnya masingmasing" (Kamil, 2010:35). Model-model pelatihan di pendidikan luar sekolah sendiri pun sangat beragam, akan tetapi yang sangat penting untuk ditekankan adalah hasil atau pengaruh dari pelatihan itu sendiri. Tentunya, setelah adanya pelatihan, peserta pelatihan akan mendapatkan perubahan pada dirinya akan kemampuan yang dimilikinya sebagaimana kondisi ini sering disebut dengan istilah luaran (out put). Tidak hanya itu saja, luaran tadi akan membentuk suatu pengaruh yang sering disebut juga dengan istilah outcome. Pengaruh ini dapat berupa penghargaan pada peserta pelatihan oleh orang lain di tempat kerja, pendapatan, penampilan diri dan penghargaan masyarakat. Oleh karenanya, pengaruh tadi akan berorientasi pada suatu kemampuan atau dikenal dengan sebutan kompetensi, juga adanya produktivitas kerja yang muaranya ke arah kinerja, dan semua itu dilatarbelakangi adanya motivasi.

Agar peserta pelatihan belajar dengan giat perlu ada motivasi. Motivasi dapat berupa pekerjaan atau kesempatan berusaha, penghasilan, kenaikan pangkat atau jabatan, dan peningkatan kesejahteraan serta kualitas hidup. Dengan begitu, pelatihan dirasakan bermakna oleh peserta pelatihan. Efektivitas program pelatihan antara lain bergantung pada para pelatih yang mempunyai minat dan kemampuan melatih. Anggapan bahwa seseorang yang dapat mengerjakan sesuatu dengan baik akan dapat melatihkannya dengan baik pula, tidak 
sepenuhnya benar. Karena itu perlu ada pelatihan bagi para pelatih. Selain itu pemilihan dan pelatihan para pelatih dapat menjadi motivasi tambahan bagi peserta pelatihan. Karena pelatihan merupakan bagian dari proses pembelajaran, maka prinisip-prinsip pelatihan pun di kembangkan dari prinsip-prinsip pembelajaran. Menurut Mc. Donald dalam Sardiman (2007:73) menyebutkan, "motivasi sebagai perubahan energi dalam diri seseorang yang ditandai dengan munculnya feeling dan didahului dengan tanggapan terhadap adanya tujuan".

Fungsi pelengkap yang diberikan oleh SSG dapat dilihat dari program kegiatan pembelajaran etika pergaulan, unlocking Potencial Power (wujud dan potensi diri), raefling, Halang Rintang, PBB, aqidah, kepemimpinan, wirausaha, dan sebagainya. Fungsi yang lain yakni pelatihan pemberdayaan masyarakat yang diberikan oleh pihak lembaga, dapat dilihat dari program pelatihan seperti bakti sosial dan pertolongan pertama gawat darurat. Oleh sebab itu, perlu adanya penelitian mengenai seberapa besar pengaruh dari pelatihan karakter baku yang diselanggarakan oleh santri siap guna (SSG). Penelitian ini dipandang perlu dikarenakan untuk mendapatkan analisis yang sebenarnya mengenai pengaruh pelatihan karakter baku, karena selama ini belum ada suatu kajian mengenai hal tersebut. Sehingga hasil penelitian ini dapat dijadikan sebagai bahan masukan bagi lembaga dan masyarakat dalam kerangka upaya pengembangan sumber daya manusia melalui pelatihan.

\section{METODE}

Pendekatan penelitian menggunakan deskriptif kuantitatif. Bertujuan mengungkap pengaruh pendidikan dan pelatihan Santri Siap Guna (SSG) terhadap peserta pelatihan. Rumusan masalah dikaji dalam empat indikator yaitu, kinerja, motivasi kerja, produktivitas, dan kompetensi peserta pelatihan. Penelitian dilakukan di Yayasan Daarut Tauhid Kota Bandung.

Teknik pengumpulan data menggunakan angket, wawancara, dan dokumentasi. Data penelitian berbentuk data kualitatif dan kuantitatif. Data yang berbentuk kualitatif dianalisis dengan mendeskripsikan data yang di peroleh dari hasil wawancara. Sedangkan data yang berbentuk kuantitatif dianalisis dengan statistik proporsional dalam bentuk presentase. Hasil analisis data merupakan gambaran bagaimana pengelola program melakukan identifikasi kebutuhan dan bagaimana proses penyusunan perencanaan program.

Sumber data penelitian diambil dari pengelola, dan para peserta pelatihan SSG yang sudah dinyatakan lulus dalam pelatihan. Sumber data yang utama didapatkan dari pengisian angket sebanyak 31 orang yang menjadi responden sebagai sampel penelitian. Wawancara dilakukan pada pengelola yang sekaligus adalah pimpinan bidang DIKLAT SSG di Yayasan Daarut Tauhid.

\section{HASIL DAN PEMBAHASAN}

Peserta didik yang mengikuti program SSG sebanyak 140 orang, Waktu pelaksanakaan untuk kegiatan pelatihan karakter baku dilaksanakan setiap hari Sabtu 16.30 dan Minggu 07.00-selesai selama 4 bulan. Program pelatihan diberikan untuk membantu peserta didik yang ingin membentuk karakter baku pada diri mulai dari akhlak sampai dengan kompetensi yang dimiliki. Sehingga setelah selesai mengikuti kegiatan pelatihan di SSG, peserta didik memiliki akhlak yang baik dan sertifikat kompetensi yang berstandart internasional. Sertifikat ini dapat dipergunakan sebagai syarat dalam mencari pekerjaan.

Pengaruh yang dirasakan para peserta alumni yang telah mengikuti kegiatan SSG dalam penelitian ini diukur dengan menggunakan angket sejumlah 31 responden pada peserta pelatihan SSG yang sudah lulus. Hasil analisis dapat diklasifikasikan kriteria standar pengaruh yang dibuat dalam bentuk persentase: kategori pertama $0-20 \%=$ STS, Kedua $20-40 \%=$ TS, Ketiga $40-60 \%=\mathrm{KS}$, Keempat $60-80 \%=\mathrm{S}$, dan Kelima $80-100 \%$ = SS. Dengan klasifikasi ini dapat diukur dari data angket yang ada, berikut hasil analisisnya sebagaimana pada gambar 1. 


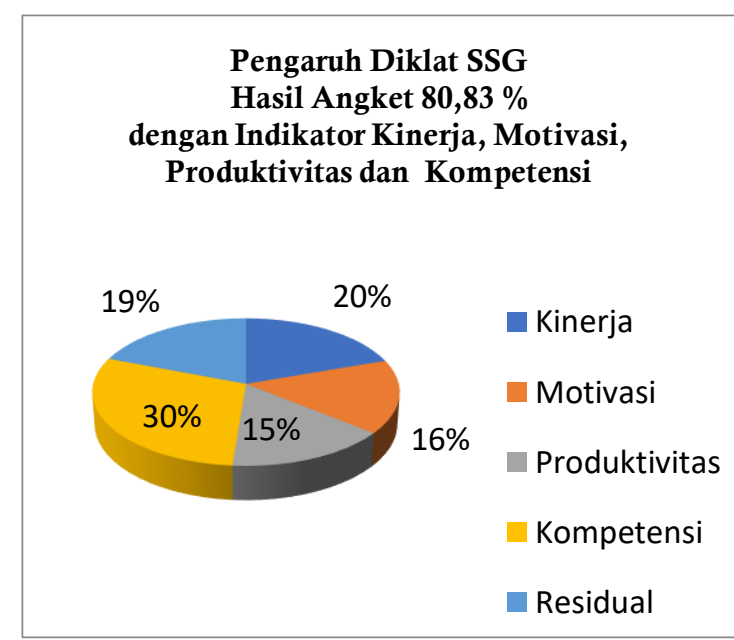

Gambar 1. Data Hasil Diklat SSG

Data yang diperoleh dapat disimpulkan bahwa pelatihan tersebut berpengaruh terhadap peserta dengan persentase $80,83 \%$. Dengan data tersebut dapat dikategorikan dalam klasifikasi tingkat ke 5 dengan kategori sangat setuju. Maka dari itu, disimpulkan dalam pelatihan ini para peserta sangat setuju bahwa pengaruh pelatihan SSG terhadap peserta dari empat indikator sangat dirasakan oleh para peserta yang sudah mengikuti kegiatan SSG.

Pelatihan yang diselenggarakan oleh pihak yayasan Daarut Tauhid dalam pendidikan dan pelatihan Santri Siap Guna, dilakukan dalam kurun waktu pendidikan yang pendek, yaitu setiap angkatannya adalah empat bulan. Penyelenggaraan pelatihan tersebut ditujukan untuk menciptakan karakter baku dan menciptakan alumni pelatihan yang mempunyai etos kerja yang baik berbasis keagamaan. Dengan kurun waktu yang pendek, dan ingin mendapatkan tujuan yang ingin dicapai, maka sesuai dengan pendapat Sikula dalam Sumantri (2000) bahwa pelatihan menjadi proses pendidikan jangka pendek yang menggunakan cara dan prosedur yang sistematis dan terorganisir. Peserta pelatihan dapat mempelajari keterampilan yang sifatnya praktis.

Para peserta berpendapat sangat setuju bahwa kegiatan pendidikan dan pelatihan santri siap guna berpengaruh terhadap peserta pelatihan dari empat indicator. Maka dari itu, harapan penyelenggara dapat terpenuhi dengan mayoritas pesertanya berpendapat baik terhadap pelatihannya. Hal ini pun sesuai dengan pendapat Simamora (1997) bahwa pelatihan dapat memperbaiki kinerja. Tujuan pelatihan dilakukan dengan tujuan meningkatkan pengetahuan dan keterampilan seseorang agar mereka yang dilatih mendapat pengetahuan dan keterampilan dalam memahami dan melaksanakan suatu pekerjaan dengan efektif dan efisien. Dengan kata lain tujuan pelatihan adalah meningkatkan kinerja dan pada gilirannya akan meningkatkan daya saing.

Kinerja adalah hasil atau tingkat keberhasilan seseorang secara keseluruhan selama periode tertentu dalam melaksanakan tugas dibandingkan dengan berbagai kemungkinan, seperti standar hasil kerja, target atau sasaran atau kriteria yang telah ditentukan terlebih dahulu telah disepakati bersama (Rivai \& Basri, 2005). Faktor-faktor yang mempengaruhi kinerja adalah efektivitas dan efisiensinya sebuah pekerjaan yang akhirnya dapat memudahkan anggota dalam bekerja dan dalam sebuah organisasi kinerja dapat dipengaruhi pula oleh otoritas pimpinan. Dimana pimpinan dapat membatasi apa yang boleh dilakukan dan tidak boleh dilakukan. Setiap anggota juga perlu punya inisiatif yang tinggi dalam bekerja, dimana ini memang tercipta untuk melawan kondisi yang berubah dengan perencanaan ataupun hal yang belum terprediksi sebelumnya, hal ini pun dapat mempengaruhi kinerja karena dengan anggota yang tidak memiliki inisiatif yang tinggi maka akan kebekuan dalam bekerja, dan kurang mampu menghadapi kondisi yang harus diputuskan sendiri dalam menyelesaikannya. Karakteristik kinerja anggota pun dapat menjadi salah satu factor yang mempengaruhi kinerja, karena dengan karakteristik manusia yang berbeda dan dengan latar belakang yang berbeda pula akan menyebabkan kinerja yang berbeda pula. Tapi hal ini bisa di antisipasi dengan kompetensi yang sama yang akhirnya setiap anggota mempunyai standar kompetensi yang sama dalam bekerja di kelasnya.

\section{SIMPULAN}

Sebesar 80,83 \% peserta pelatihan sangat setuju bahwa adanya pelatihan santri siap guna 
berpengaruh terhadap kemampuan peserta. Kemampuan peserta tersebut diukur dalam empat indikator, yaitu indikator kinerja, motivasi, produktivitas dan kompetensi. Perolehan indikator kinerja sebesar 19.67\%, motivasi sebesar $16,17 \%$, produktivitas $15,41 \%$, dan kompetensi 29,64\%.

Perlu adanya keberlanjutan program kegiatan santri siap guna dalam membekali pelatihan peserta didik. Utamanya adalah bagi mereka yang telah memiliki pekerjaan baik yang memiliki usaha mandiri ataupun bekerja di perusahaan. Kemampuan motivasi dan produktivitas peserta hasil pelatihan menjadi prioritas untuk ditingkatkan. Demikian pula perlu adanya penelitian keberlanjutan untuk mengetahui variabel lainnya dari pengaruh penyelenggaran pelatihan.

\section{DAFTAR PUSTAKA}

Depdiknas. (2004). Pedoman penyelenggaraan program kecakapan hidup (life skills) pendidikan nonformal. Jakarta: Ditjen Diklusepa.

Kamil, M. (2010). Model pendidikan dan pelatihan (konsep dan aplikasi). Bandung: Alfabeta.

Rivai, V., \& Basri, A. F. M. (2005). Performance appraisal: Sistem yang tepat untuk menilai kinerja karyawan dan meningkatkan daya saing perusahaan. Jakarta: PT Raja Grafindo Persada.

Simamora, H. (1997). Manajemen sumber daya manusia. Yogyakarta: Bagian Penerbitan STIE YKPN

Sudjana, D. (2004). Pendidikan nonformal: Wawasan, sejarah perkembangan, filsafat, teori pendukung, asas. Bandung: Falah Production.

Sumantri, S. (2000). Pelatihan dan pengembangan sumber daya manusia. Bandung: Fakultas Psikologi Unpad. 